\title{
The Form of Bureaucracy Reformation Under the Strong Regional Head in Indonesia
}

\author{
Andi Rusli ${ }^{1}$, Sukri $^{2}$, Ashar Prawitno ${ }^{3}$ \\ \{andirusli2707@gmail.com ${ }^{1}$, sukripolitik@gmail.com², asharprawitno@gmail.com³ \\ Faculty of Social and Political Sciences, Hasanuddin University \\ Jl. Perintis Kemerdekaan Km. 10, Makassar, Indonesia ${ }^{1,2,3}$
}

\begin{abstract}
Bureaucracy is an important figure in an institutional work system in both business and government organizations. In the context of government, bureaucracy is an institution that is the executor of all government policies as a reflection of the power of the head of government. Thus it is necessary to ensure that the bureaucracy remains professional. However, the phenomenon of the northern Mamuju district shows that the existence of a strong local figure as the head of the region will affect the figure of the bureaucracy. Although the effort to make the bureaucracy a neutral institution serving the people, but it seems to have to deal with the tendency of the bureaucracy to be part of an effort to maintain the power of regional authorities. In the end, the bureaucratic reform effort is faced with a dilemmatic condition for the bureaucracy. In one hand, bureacracy reform objectives is to create more profesional bureaucracy that netral form political interest of particular actors, but on the ither hands it also should obey their leader as part of the regional government staf.
\end{abstract}

Keywords: Mamuju Tengah, Bureaucracy Reform, Profesional, Strong Regional Head

\section{Introduction}

Bureaucratic system under the weberian perspective. This thinking places the bureaucracy as a professional figure that regardless of influence of the political power of its rulers. Through bureaucracy, it is expected that the bureaucracy could carried out its public services maximal and professionally. This is important due to bureaucracy is a solid structural system which is providing public services on various aspects of people's lives as part government institution. It puts the bureaucracy as a important structure to support the dynamics of people's lives and their development.

However, in some cases, it is often where bureaucratic reform efforts does not success as it expected. It is usually related to various things. The existence of regulations in the regional context, leadership and the carrying capacity of the system are usually as things that influence the efforts for bureaucratic reform in various government level. If there are parts that do not provide maximum support the effort potentially will fail. In the context of regional government, one important aspect that important for the bureaucracy reform effort is the regional leader.

Based on this picture, this paper aims to analyze several factors that influence efforts of bureaucratic reform. Based on the field research was in the Central Mamuju Regency (Kabupaten Mamuju Tengah), West Sulawesi Province, Indonesia. This regency is one of the interesting areas to analyse the bureaucratic reform related to its context of the strong leadership tendency. This aspect indicate a unique condition due to the regional head with his strong political and formal authority that basically tends to produce a binary position of the reform 
effort. The strong authority potentially results good effort to create professional bureaucracy. But, in the same time it is also potentially made a bureaucracy structure that focus to serve the leader political agenda.

\section{Research Method}

This paper is based on the results of field research conducted in the Mamuju Tengah regency, Province of South Sulawesi Province, Indonesia. Based on the qualitative study emphasizing in the case studies, this study intends to show how the strong and centralistic leadership in the regional government influences dynamics of reform and at the end the forms of bureaucracy in this socitey context. During this research, the Primer data was colleted thru direct interview with some relevant key informants while the secunder data taken from various references, file and notes from relevant instituions.

\section{Result And Discussion}

\subsection{Weberian Concept of Profesional Bureaucracy}

Basically, bureaucracy is a concept that is very commonly known related to work systems in business and government. Bureaucracy as the personnel and administrative structure of a meeting. This system applies to large workforce arranged in a hierarchical structure to carry out specific tasks in accordance with the internal rules and procedures of the institution. Bureaucracy is an administrative system designed to complete large-scale administrative tasks by integrating the work of many individuals.

Max Weber is one of the main figures in modern bureaucratic studies. Weber's thinking is closely related to a form of bureaucracy which is a professional work structure oriented towards the purpose of relations based on existing rules. Max There are three types of power in organizations: traditional, charismatic and rational-law or bureaucracy [1]. In this case, Weber's main agreement was related to the concept of bureaucracy, namely the main understanding of certain characteristics in an organization which he called government by the bureau. Max Weber's formulation of the concept of bureaucracy can be done as a recovery point to find data to understand the structure or hierarchy in which the policy making process takes place [2].

Furthermore, according to Max Weber's bureaucratic theory, bureaucracy is the basis for the organization of each organization and is designed to ensure economic efficiency and ease. This is the ideal model for management and administration to create a power structure. With this in mind, he established the basic principles of bureaucracy and governed the division of labor, hierarchy, rules and impersonal relations.

In the beginning Weber's theory was developed from Prussian military forces, and which companies like the British Railroad Company were actually found in the ranks of the British Army, were to be a special form of managing large businesses. Weber accepts that the emergence of modern bureaucratic organizations is 'demanded', he further said 'the peculiarities of modern culture', and specifically from a technical and economic basis, require 'calculation of results' [3]. Max Weber declared the concept of Bureaucracy in a given context regarding the unavoidable situation of society [4]. In this case, Weber stated that bureaucracy is a figure who works rationally where his rationality is placed on the structure of professional rules. 
In the context of professionalism, by referring to Weber's thinking there are at least six main principles in the bureaucratic figure that shows the nature of his professionalism. These principles are: 1) Task Specialization which means there is a division of routine work based on competence and specialization that can be done by employees. Through the division of the organization will receive benefits because each section works in accordance with the capabilities and functions. In the institutional work system; 2) Hierarchical Authority which means that each layer of management is responsible for staff and overall performance in a structured and hierarchical manner; 3) Formal Selection means that all employees are selected based on technical skills and competencies, which have been obtained through training, education, and experience. Thus, the staff procurement process is not based on the subjective trends of certain people in the institution but based on the quality and capability of each person; 4) Rules and Requirements means that there are formal rules and requirements that are used to ensure uniformity, so employees know exactly what is expected of them where all administrative processes are defined in official rules; 5) Impersonal means Regulations and clear requirements create a distant and impersonal relationship between employees, with the added benefit of preventing nepotism or involvement of outsiders or political interests. This impersonal relationship is a prominent feature of bureaucracy. Interpersonal relations are merely characterized by a public legal system and rules and requirements; 6) Career Orientation means employees are chosen based on their expertise. This helps in spreading the right people in the right positions and thus utilizing human resources optimally. Proper division of labor also allows employees to specialize themselves further, so they can become experts in their own fields and significantly improve their performance [5].

The various indicators of bureaucratic professionalism that Weber emphasized basically show that the figure of the bureaucracy is a structure of work that is free from the intervention of external forces in this case political powers. Although the bureaucratic system may work in a particular political system and become part of a certain political power regime, this institution is a work system that is bound by professional aspects and is not controlled by certain interests of the authorities except the interest to provide services to the community. Thus, whoever the ruler and whatever form of ruling the bureaucracy will remain professional. In this case professionalism is a key word so various efforts to encourage the development of bureaucracy will always occur based on professional indicators.

\subsection{Strong Leader and the effect on the Bureaucracy Reformation in Mamuju Tengah}

One of important form the present of bureaucracy in many places of Indonesia is the tendency of tight control from the head of regional government the bureaucracy. It make bureaucracy seems stand at the two oppositional position, as the profesional institution as Weber mention or became part of the local power authority that tends to serve the rulling group. It become as important situation should be views critically due to the central government has it own objective to reform bureaucracy under the profesional prinsiples of Weberian perspective of bureaucracy.

Bureaucratic reform is carried out in the context of realizing good governance. In other words, bureaucratic reform is a strategic step to build the state apparatus to be more efficient and effective in carrying out the general tasks of government and national development. This bureaucratic reform is carried out by considering the background as follows [6]:

- Corruption, Collusion and Nepotism (KKN) practices are still ongoing.

- The level of quality of public services that have not been able to meet public expectations. 
- The level of efficiency, effectiveness, and productivity that are not optimal from the government bureaucracy.

- The level of transparency and accountability of government bureaucracy is still low.

- The level of discipline and employee work ethic is still low.

According to Riswanda, the etymological meaning of "reform" from the word "reformation" with the root word "reform" which semantically means 'make or become better by removing or putting right what is bad or wrong'. Literally reform has a meaning: a movement to reformat, reorganize things that deviate to be returned to the original form or form in accordance with the ideal values aspired by the people [7].

From the description above, it can be concluded that the reformation carries the message to restore and make changes to the rule of law system in the true sense as contained in the explanation of the 1945 Constitution, namely there must be protection of human rights, justice free from the authorities, and legality in the legal sense. Therefore reform itself must be based on a clear legal framework. Besides reforms must be directed at a change towards transparency in a policy in the administration of the state [7]. It means all reformation efforts in Indonesia should create a more profesional bureaucracy including in Mamuju Tengah.

Bureaucracy system in the Mamuju Tengah actually should be subject to the central government reform agenda where seemly under the Weberian perspective. But due to the unique context of the region especially the local government leadership, it is possible that the reform as desired by the central government will deal with the interests of the regional leader about how the form of the bureaucracy should be. It because the regent of this district is a powerfull political actor where succeed to win his recent position by win more than $90 \%$ voters. It made him as the powerfull actor that also control the system of bureaucracy in the region.

As strong local politician, that is usual where he tends to keep the bureaucray under his full command. It tends to confront the bureaucracy in this region a dilemmatic situation. Due to the bureaucracy reform is related to many processes wher usually overlaping with many government functions, this effort then requires a good will of all aspect including the regional heads. Thus for the regional head, the reform places bureaucracy in two dilematic situations, a subject of central bureaucratic reform scheme that leads to the professionalism or became as the tool of the regional political interests.

With the great power based on constitution and his social context, the regent of Mamuju Tengah became a central figure. He sholud bridging the efforts of bureaucratic reform from of the central government in Central Mamuju district. It means, formally his authority could allows the succeed of the efforts. Due to his prominent position in social and political aspect, it can be said that reform in his area relies heavily on his vision, mission and goodwill as the head of the regional government. it means the bureaucratic reform will depend deeply on the interests him as the regent as well as the important social and political actor.

By viewing the socio-political context in the Mamuju Tengah, the recent regent has opportunity to direct the bureaucratic system to his interests. He need it not only to keep his authority and power nowdays but also to guarrantee the continuity of his control of this district. By control the political dynamics, He could keep his possesion to keep the important resources even in social, politics or economical resources. As an institution that regulates various aspects of people's lives, ability to control it will provide opportunity to use it in shaping the social and political systems in the region based on his interests. It means, the bureacracy will potentially controlled the reform agenda deeply will related to his good will and its coherence objectives. The fact then confirmed that the reform policy of the central government on the bureaucracy will faced a challenging condition if the reform trully produced the Weberian prefesional bureucracy. Since bureacuracy is the effective structure to keep the leader control on people and 
most resources then every effort to make it as profesional structure will seen as the tendency to reduce the leader control and authority.

At the end, the form of bureaucracy under the reform concept potentially produce a marxian bureaucracy tfor the leader interest. It because, the strong position of the leader tend to create an exclusive authority where it is in his hand. In this circumstences, the power to control bureacracy possible will use as the tools to increase access to the resources not only for him but also for his group. Therefore, the bureacracy will possibly playing not as the trully and profesional civil servant but as the part of the rulling group server.

\section{Conclusion}

As the conclussion, the bureaucratic reform in the context of regional government authority such as in the Mamuju Tengah is very likely to lead efforts to establish supporting tool for the ruler interst. The magnitude of the influence of bureaucracy in the community makes it as an important structure for the regional authorities to ensure the existence and sustainability of its power. it means even there is an agenda of reformation for the bureaucracy from the Central Government, but it stand within the local context where a strong leader has his influence to the local structure of bureaucracy that seen strong controlled by the ruler.

Thus, the bureaucratic reform in Indonesia, which is as a national agenda, could basically switched to form of political servant for the regional head government political interest. It means, the effort to reform bureaucarcy to be as the profesional civil servant will faced fact that it also part of the regional government head who usually has his own interest and agenda that put bureaucracy as tools to keep it.

\section{References}

[1] Spencer, M. E.: Weber on legitimate norms and authority. The British Journal of Sociology, 21 (2) pp. 123-134 (1970)

[2] Lutzker, Michael A.: Max Weber and the Analysis of Modern Bureaucratic Organization: Notes Toward a Theory of Appraisal. American Archivist/Vol. 45, No. 2/Spring, pp. 119-130 (1982)

[3] Clegg, Stewart and David Dunkerley.: Organization, class and control. Routledge \& Kegan Paul, London (1980)

[4] Serpa, Sandro and Carlos Miguel Ferreira: The Concept of Bureaucracy by Max Weber. International Journal of Social Science Studies Vol. 7, No. 2; March, pp. 12-18 (2019)

[5] Page, Edward C.: Farewell to the Weberian State? Classical Theory and Modern Bureaucracy. ZSE 4, pp. 485-504 (2003)

[6] Wardana, Data dan Meiwanda G.: Reformasi Birokrasi Menuju Indonesia Baru, Bersih dan Bermartabat. WEDANA Jurnal Pemerintahan, Politik dan Birokrasi. Vol. III Nomor 1 April, pp. 331-336 (2017)

[7] Rosalina, Ginting dan Haryati, T.: Reformasi Birokrasi Publik di Indonesia. Jurnal Ilmiah CIVIS, Volume I, No 2, Juli, pp. 27-41 (2011) 